\title{
MISTLETOE (VISCUM ALBUM L.) DAMAGE AND ITS ECONOMIC EFFECTS IN SCOTS PINE (PINUS SYLVESTRIS L.) NATURAL REGENERATION AND AFFORESTATION AREAS
}

\author{
ERTUĞRUL, M. H. ${ }^{1}-$ KomUT, O. $^{2^{*}}$ \\ ${ }^{1}$ Department of Forestry, Kürtün Vocational High School, Gümüşhane University, 29000 \\ Gümüşhane, Turkey \\ ${ }^{2}$ Department of Forestry, Gümüşhane Vocational High School, Gümüşhane University, 29000 \\ Gümüşhane, Turkey \\ *Corresponding author \\ e-mail: osmankomut@gumushane.edu.tr; phone: +90-456-233-1060; fax: +90-456-233-1067 \\ (Received $14^{\text {th }}$ Sep 2019; accepted $15^{\text {th }}$ Nov 2019)
}

\begin{abstract}
This study discusses the development of mistletoe (Viscum album L.) and its economic impacts on natural afforestation and regeneration areas. In this context, a total of 16 sample areas were determined in Scots pine natural regeneration and afforestation areas with resembling habitat characteristics. The occurrence status of mistletoe in Scots pine (Pinus sylvestris L.) individuals in these areas was determined according to stem, branch and corolla parts and morphological age determination was also conducted for the plants. Additionally, the relationship between diameter and length increase of healthy individuals, and ones affected by mistletoe were modelled with simple linear regression analysis. Besides, the tree asset values of the stands were calculated by estimating maintenance and afforestation costs at the working sites, and economic loss potential was determined through the targeted forest product revenue. Study results have revealed that natural regeneration sites are less exposed to mistletoe damage than afforestation sites. While the mistletoe exposure was found to be $27 \%$ in the study areas, it was determined that there was a potential revenue loss of $21 \%$ concerning the target economic revenue as well as additional labour and afforestation costs.
\end{abstract}

Keywords: forest cultivation, mistletoe, revenue loss, parasitic plant

\section{Introduction}

Mistletoe is an evergreen hemiparasite plant which has chlorophyll to be able to make photosynthesis and can live in the branches and trunks of trees (Yüksel et al., 2005). There are 36 genus and 1400 species of mistletoe which have been identified throughout the world. Mistletoes spread generally in temperate and tropical zones. The parasitism characteristic of mistletoe was revealed first in $305 \mathrm{BC}$. and was described for the first time by the Greek botanist Theophrastus (Janssen, 2001; Zuber, 2004). Mistletoe is part of the Santatales order of Viscaceae (Loranthaceae) family. It has three subspecies as $V$. album ssp. album: observed in all trees, $V$. album ssp. austriacum: frequently in pine species, V. album ssp. abietis in firs (Bilgili et al., 2014). Mistletoes are observed in almost all Scots pine forests spreading in Turkey (Eroğlu and Başkaya, 1995; Zuber, 2004).

Mistletoe seeds are consumed fondly by the nectar birds. The mistletoe seeds stick firmly to the branches thanks to their adhesive covering and fibres on their outer surfaces (Frochot and Salle, 1980). Often the first contamination is observed in old trees and large branches. The reason for this is explained by that birds arrive at the top of tall trees (Yüksel et al., 2005). Mistletoe seeds which sprout on individuals express themselves through the bark with the radicles. Absorbent aerial roots growing from the 
radicles penetrate into the cortex and advance to the cambium of the host individual. Lateral roots advancing down and up occur from roots which reached cambium (Glatzel, 1983; Tennakoon and Pate, 1996; Anonymous, 1998). These radicles form 1-2 radicles each year, but they do not exhibit an active grow into the wood. However, they show growth as each annual ring thickness and passively enter into the wood (Yüksel et al., 2005). The mistletoe disturbs the normal growth by using the host plant's mineral nutrients via their absorbent roots, thus weakening the host plant and often it results in the loss of vital functions. Besides, they create swelling in the branches they occupy and prevent the use of these parts (Popp and Richter, 1998; Zuber, 2004; Yüksel et al., 2005). It has been reported that the anatomic parameter values of individuals with mistletoe contamination vary between $19-82 \%$ (Göl et al., 2018). It is known that the volume and quality of timber to be obtained from logs are also affected by natural and ecological conditions (Mutanen and Toppinen, 2007; Malinen et al., 2015; Merganič et al., 2016; Gejdoš et al., 2019). It is also reported that biotic and abiotic pests have important effects on this issue (Fidan et al., 2016; Yaşar et al., 2016).

It is recommended that cleansing the mistletoe contaminated trunk parts by scraping and preventing any contact of these parts with sunlight and air are among recommended precautions. In the case that the mistletoe is observed on the branches, it is recommended that these branches are cut and removed (Yüksel et al., 2005). It is found that mistletoe affects the industrial use of the tree as well as economic losses because of the maintenance works which would be conducted. In addition, anomalies in the woodbased products introduced to the market adversely affect the demand of consumers (Öztürk, 2010).

In this study, it is aimed to determine the effect of mistletoe on the increase and growth, thus to determine the economic loss it causes by investigating Scots pine afforestation and natural regeneration areas in terms of mistletoe exposure.

\section{Materials and methods}

\section{Materials}

Research was conducted in Gumushane province of Turkey. Natural rejuvenation and afforestation areas within the borders of Gümüşhane Forest Management Directorate were selected as the study area. The working area is between $40^{\circ} 32^{\prime}$ and $40^{\circ} 14^{\prime}$ northern latitudes and $39^{\circ} 56^{\prime}$ and $40^{\circ} 20^{\prime}$ east longitudes (Fig. 1). In this context, the attention has been paid to work in areas where there are no significant elevation differences, slope and habitat differences in order to better deliver the differences between natural regeneration areas and afforestation areas. The average elevation of the study area has been measured as $1690 \mathrm{~m}$ in natural regeneration areas and as $1710 \mathrm{~m}$ in afforestation areas.

Sampling areas were determined as a result of the investigations for natural regeneration areas and afforestation areas which do not have slope, elevation and serious elevation differences under the same habitat conditions, by using the current stand map (Fig. 2).

Eight sample areas have been determined in the 162 numbered natural regeneration area which is 16.9 ha, 8 sample areas have been determined in the 207 numbered afforestation area which is $26.8 \mathrm{ha}$, and in total 16 sample areas have been determined. These areas have been determined as $100 \mathrm{~m}^{2}$ in Çsa natural regeneration areas which are in "a" age and as $200 \mathrm{~m}^{2}$ in Çsab afforestation areas, which are in "ab" age, as stated in 
the management plans. The difference of the sample size of the selected area was due to the different size of the area of natural regeneration and afforestation. The stands of the selected sample areas have been transformed into Google Earth image by digitizing the existing stand maps with the help of Netcad program. Field works were carried out in April and May 2018.

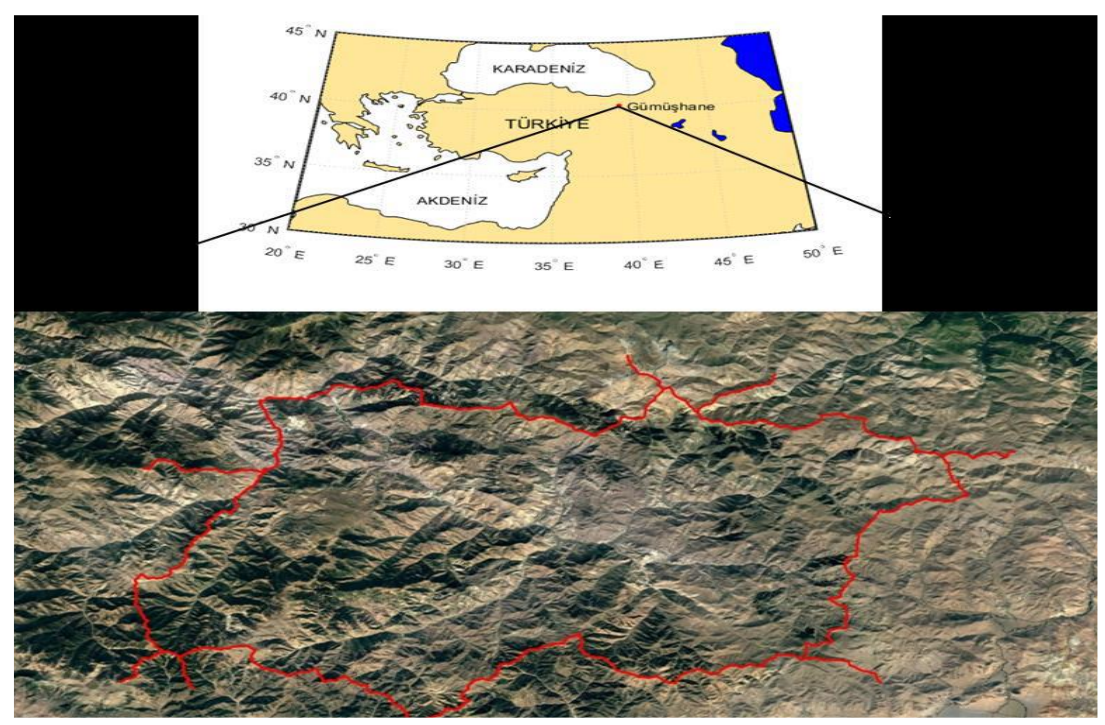

Figure 1. General location of the research area

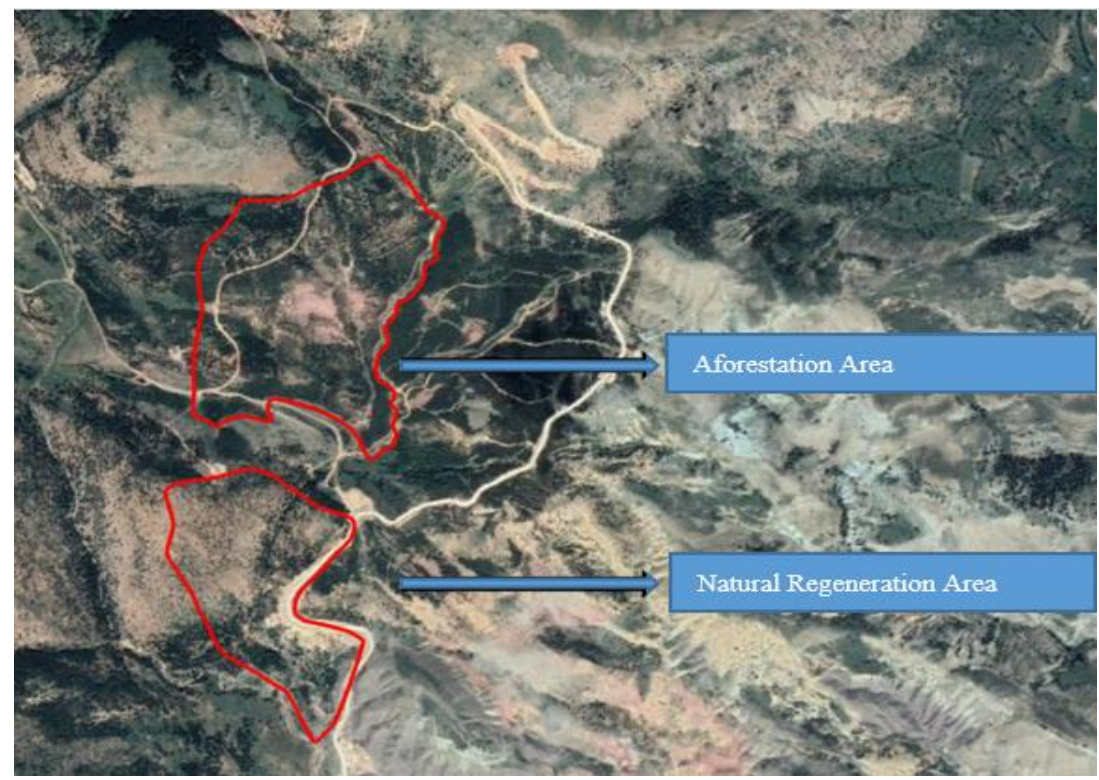

Figure 2. Sample areas of the research area

\section{Methods}

Diameter and length measurements were conducted for each tree in the sampling areas. On the other hand, the mistletoe age was determined with the morphological age determination method for individuals in the sampling areas. The diameter of the trees 
was measured as $\mathrm{d}_{130}$ diameter by using a calliper. The length of the trees was measured with the help of SILVA CM 10152025 LA DP slope and length measuring compass. In this study, each tree has been divided into three parts as trunk, branch and canopy and mistletoe contamination conditions were determined in all trees that were analyzed. In this study, the power of mistletoe infection was evaluated on the basis of contamination on the top, branch and trunk of the tree, the age of exposure of the trees to the infection and the age of the mistletoe detected. The parameters of the infected and non-infected trees were evaluated together in order to analyze the effects of mistletoe on the development of individuals.

In order to determine the relationship of mistletoe contamination in the sampling areas with the diameter and length, t-test application was carried out with the help of the SPSS program. T-test, which is used to determine the differences between the variances of 2 independent variables, was utilized in order to identify whether or not there is a difference between the determined natural regeneration areas and afforestation areas for mistletoe contamination. In addition, one-way variance analysis and Tukey HSD PostHoc test were applied for identification of the difference in the sample areas in terms of contamination status.

Simple linear regression analysis was conducted to form the growth models of healthy individuals and individuals where mistletoe was observed. The tree assets cost value of the research area was determined primarily, in order to determine the economic value losses that might arise because of the mistletoe observed in natural regeneration and afforestation areas (Türker, 2013). In this context, afforestation costs, land value, annual administration costs, interest rates and economic revenue obtained as a result of the previous maintenance interference were determined. On the other hand, the economic damage of Forestry Managements (FM) from $1 \mathrm{~m}^{3}$ Scots pine wood product has been determined by assuming that mistletoe spread has stopped. While calculating this loss, the product classes which Gümüşhane FM can obtain in the future and today have been taken into consideration.

Tree assets cost value (TACV) was calculated with Equation 1 (Türker, 2013).

$$
A S M D=(c+B+V) * 1.0 P^{m}-(B+V)-\left(D_{a} * 1.0 P^{m-a}+\ldots\right)
$$

c: cost of afforestation, $\mathrm{B}$ : land value, $\mathrm{V}$ : annual administration costs, $\mathrm{P}^{\mathrm{m}}$ : interest rate, $\mathrm{P}^{\mathrm{m}-\mathrm{a}}$ : the revenue received with the inference maintenance conducted before.

\section{Results and discussion}

In the natural regeneration and afforestation areas, 330 Scots pine individuals were examined in the 16 sample areas.

It was determined that 19 of 203 individuals were determined to be exposed to mistletoe in the natural regeneration area and 60 of 127 individuals were determined in the afforestation area (Table 1).

Afforestation areas were identified to be exposed to more mistletoe damage than natural regeneration areas. On the other hand, the mistletoe was found out to be the most effective on the trunks of the individuals, the least damage occurred on the top parts (Fig. 3). Age measurement was neglected due to the evaluation that the ages of the individuals in the sample areas where the study was conducted were approximately the same. 
Table 1. The main findings concerning the study area

\begin{tabular}{c|c|c|c|c|c}
\hline $\begin{array}{c}\text { Sample field } \\
\text { attribute }\end{array}$ & $\begin{array}{c}\text { Sample } \\
\text { field }\end{array}$ & $\begin{array}{c}\text { Number of trees } \\
\text { in sample area }\end{array}$ & $\begin{array}{c}\text { d130 diameter } \\
\text { average (cm) }\end{array}$ & $\begin{array}{c}\text { Length } \\
\text { average (cm) }\end{array}$ & $\begin{array}{c}\text { Number of trees } \\
\text { infected with mistletoe }\end{array}$ \\
\hline \multirow{5}{*}{ Natural } & 1 & 9 & 9.44 & 460 & 4 \\
& 2 & 14 & 5.21 & 290 & 2 \\
regeneration & 3 & 61 & 3.06 & 200 & 4 \\
& 4 & 7 & 11.5 & 650 & 4 \\
& 6 & 13 & 6.15 & 300 & 1 \\
& 7 & 50 & 3.77 & 240 & 3 \\
& 8 & 33 & 1.43 & 84 & 1 \\
& Total & 203 & 9.75 & 598 & 0 \\
& Average & 25.38 & - & - & 19 \\
& 1 & 22 & 11.52 & 518 & 2.38 \\
\hline \multirow{5}{*}{ Afforestation } & 2 & 17 & 13.16 & 494 & 8 \\
& 3 & 7 & 15.25 & 487 & 2 \\
& 4 & 9 & 15.83 & 622 & 4 \\
& 5 & 13 & 12.05 & 437 & 7 \\
& 6 & 17 & 10.97 & 491 & 8 \\
& 7 & 18 & 9.03 & 450 & 10 \\
& 8 & 24 & 10.65 & 439 & 19 \\
& Total & 127 & - & - & 60 \\
& Average & 15.88 & 12.31 & 492.25 & 7.5 \\
\hline Total & 16 & 330 & - & - & 79 \\
\hline Average & - & 20.63 & 9.30 & 422.50 & 4.94 \\
\hline
\end{tabular}

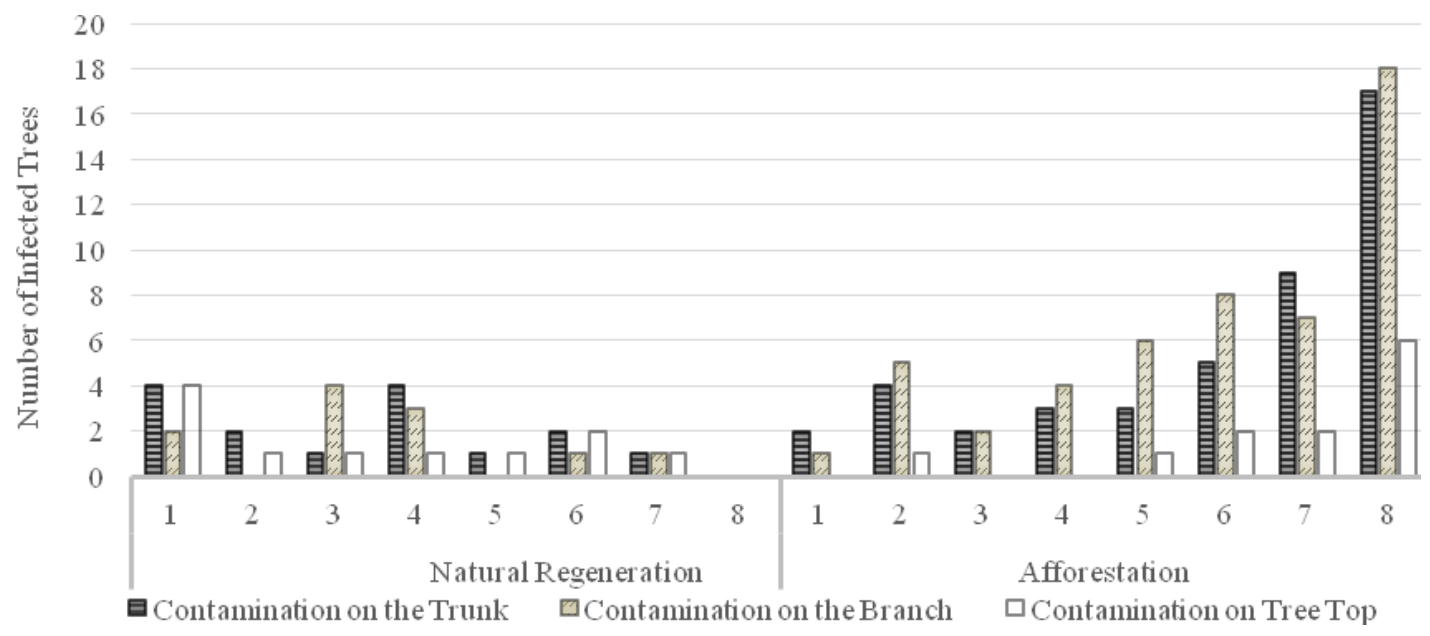

Figure 3. Contamination status of mistletoe damage to trunk parts

In the evaluations conducted, it is determined that the mistletoe occurs especially in the trunk parts, which is valid for both natural regeneration and afforestation areas. On the other hand, it was found out that the contamination to the top of the individuals in 
the natural regeneration areas has occurred earlier and close to the time of the occurrence in the trunk. In afforestation areas, it was found that the contamination to the top of the trees occurred approximately 3 years after the contamination to the trunk (Fig. 4). As a result of the morphological age measurement, the average mistletoe age detected in the trunks was detected as 6 in the natural regeneration area, the average mistletoe age was detected as 4 in the branches and the average mistletoe age was detected as 4 in the canopy. In the afforestation areas, the mistletoe age was observed as 7 in the trunk, the mistletoe age was observed as 6 in the branch and the mistletoe age was observed as 3 in the canopy. As a result of the field study conducted, mistletoe contamination was detected in 15 sampling areas and no mistletoe was observed in only 1 area.

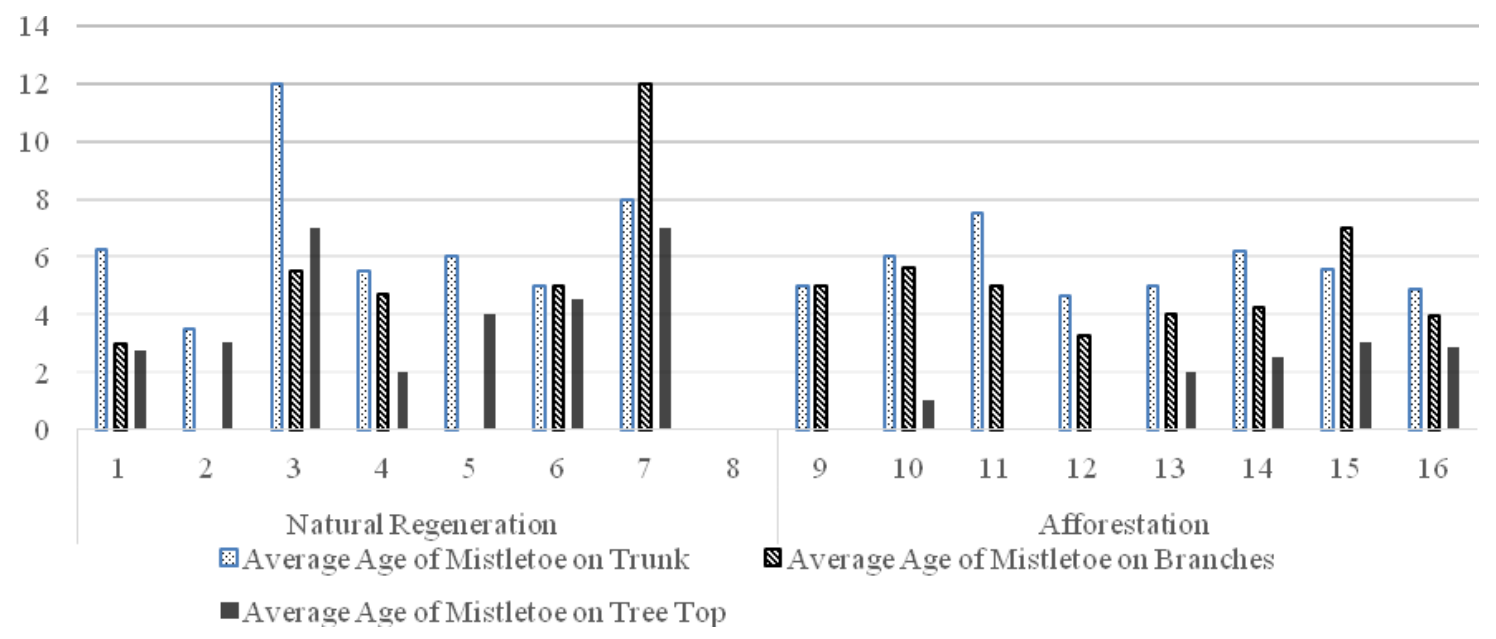

Figure 4. Mistletoe age status in the sample areas

As a result of the Single Sample T-Test we carried, it was found that the mistletoe exposure has increased as the $\mathrm{d}_{130}$ diameter and length of the individuals increased in the study areas. It can be said that the difference in question arose from the fact that mistletoe can receive more water and mineral nutrients from individuals with good diameter increase and thus show better development. Eroğlu and Başkaya (1995) have proved that mistletoe leads to an increase in the loss with $16-55 \%$ in the Scots pine individuals. It has been revealed in previous studies that mistletoe gets completely deteriorated of its closure as a result of fire, grazing and irregular exploitation and that it has affected negatively the stand increase by $8.5-16.5 \%$ in Sürmene-Çamburnu Scots pine forests (Sönmez, 2014). Sekendiz (1984) states that the annual increase loss of individuals will be $20 \%$ in the situations where the mistletoe is dense. Therefore, the processing of low diameter logs from these trees will decrease productivity and increase processing costs (Rast, 1974; Luppold and Bumgardner, 2019).

Conducted analyses showed that mistletoe exposure has occurred at a higher level in long individuals (Fig. 5). This difference can be said to be due to the fact that mistletoe can get more water and mineral nutrients from individuals with good length increase and thus enable better development. In a previous study, mistletoe was found to negatively affect the development of scots pine by 47\% (Sönmez, 2014). Çatal and Carus (2011) found in a different study they carried out that the adverse impact of mistletoe is in the range of 26-63\%. Similarly, Kanat et al. (2010) reported that 
mistletoe negatively affected 22\% increase in diameter in larch. Besides, Eroğlu (1993) has shown that the chemical structure of wood is deteriorated in scots pine individuals, where mistletoe contamination is observed, and therefore its usage properties are affected by this situation. According to Eroğlu and Başkaya (1995), while the rate of trees that dried in these forests was $1-2 \%$ per year ten years ago, it increased to $3.5 \%$ in recent years.

On the other hand, it is determined that mistletoe spread occurs more densely in afforestation areas than natural regeneration areas. All together statistically significant $(\mathrm{p}<0.05)$ differences were identified between these areas in terms of mistletoe contamination (Fig. 5). The reason for this situation can be said to be that the afforestation areas are close to the old stands where mistletoe spread is observed, and the maintenance works conducted in these areas decrease the closeness. On the other hand, the presence of dense mistletoe which is detected especially in seed trees in natural regeneration areas has been observed to affect the young scots pine individuals living nearby.

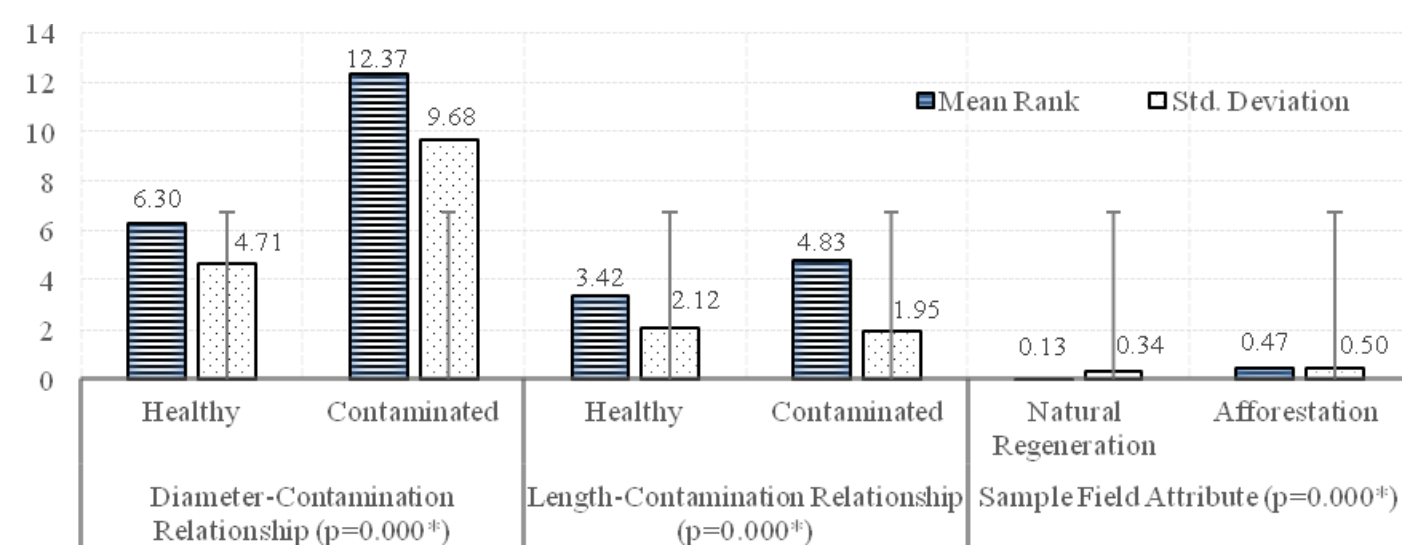

Figure 5. Statistical comparisons concerning mistletoe contamination

The results of the statistically significant differences between the sampling areas are given in Table 2 in terms of mistletoe exposure. According to this, only difference were found between the sample areas 4 and 8 in natural regeneration sample areas. In the afforestation sample areas, the differences were identified between field 9, field 15 and 16. On the other hand, the differences were determined between all-natural regeneration and afforestation sample areas except for areas 1 and 4. Table 2 shows the differences between the natural rejuvenation sample sites with $(O)$, the differences between the afforestation sample sites with $(\mathbf{O})$ and the differences between the two sites with $(\mathbf{O})$.

The findings concerning simple linear regression analysis conducted on healthy and mistletoe contaminated individuals in natural regeneration areas and afforestation areas are given in Table 3. In the study conducted on healthy and mistletoe contaminated individuals, the length was chosen as a variable depending on diameter and growth model equation, which reveals length values of individuals with respect to diameter, was developed (Table 3; Eqs. 2 and 3).

The obtained growth model revealed that mistletoe has an ever-increasing negative effect on the development of individuals. It has been emphasized in previous studies that the scots pine individuals in natural regeneration and afforestation areas lose their vital functions because of the mistletoe pest (Yüksel et al., 2005). 
Table 2. Differences between sample areas according to the Tukey HSD post-hoc test

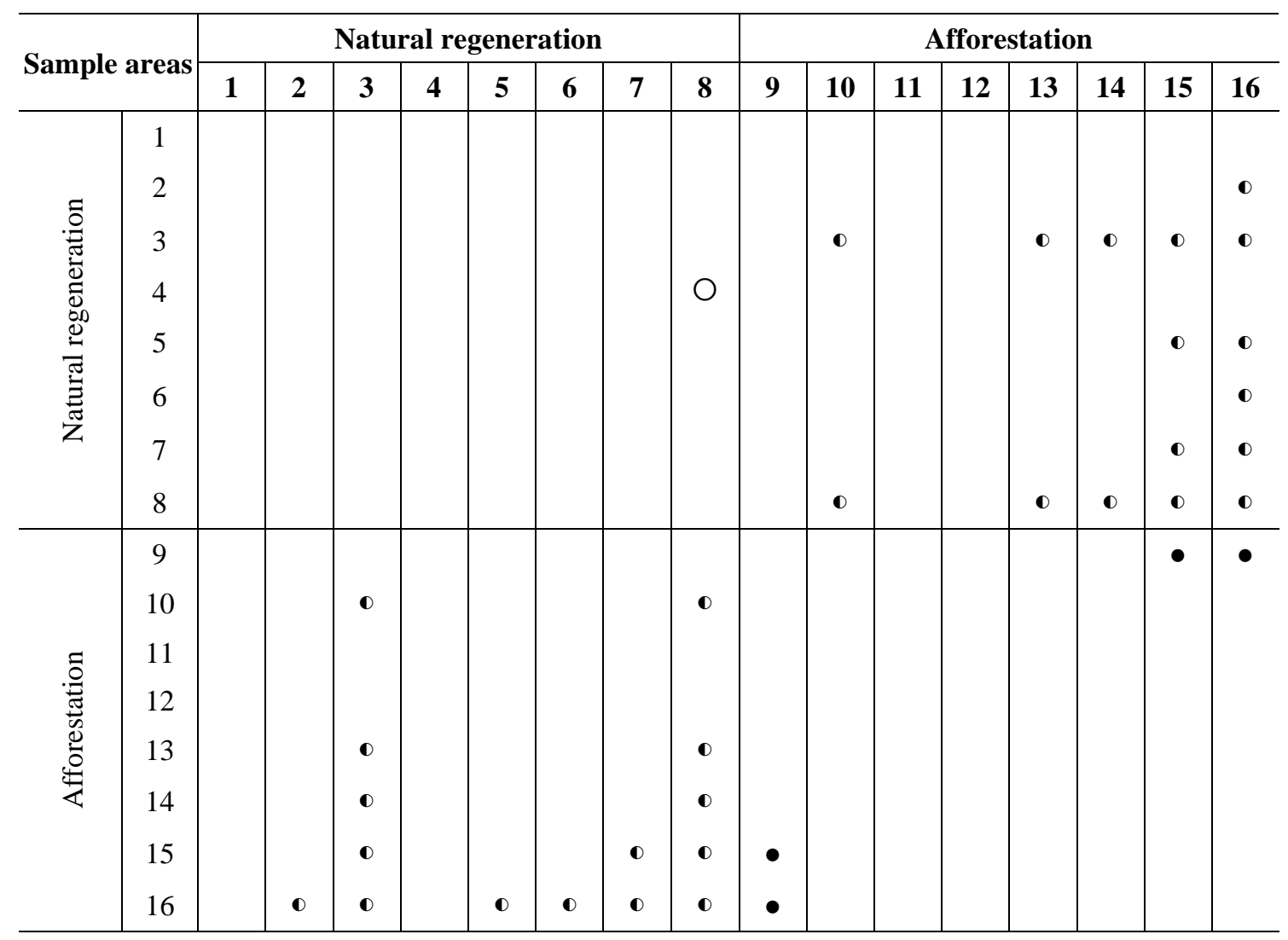

Table 3. Simple linear regression analysis results for length variable according to diameter

\begin{tabular}{c|c|c|c|c|c|c}
\hline \multicolumn{2}{c|}{ Variables } & B & Std. error & Beta & t & p \\
\hline \multirow{2}{*}{ Infected individuals } & Constant & 3.912 & 0.318 & \multirow{2}{*}{0.369} & 12.301 & $0.000^{*}$ \\
& Diameter & 0.074 & 0.020 & & 3.663 & $0.000^{*}$ \\
\hline \multirow{2}{*}{ Healthy individuals } & Constant & 0.999 & 0.121 & \multirow{2}{*}{0.867} & 8.231 & $0.000^{*}$ \\
& Diameter & 0.386 & 0.015 & & 24.953 & $0.000^{*}$ \\
\hline
\end{tabular}

$\mathrm{P}<0.05$

The length equation in individuals where mistletoe is observed:

$$
\text { Length }=3.912+0.074 * d_{1.30}
$$

Length equation in healthy individuals:

$$
\text { Length }=0.999+0.386 * d_{1.30}
$$

The regression analysis trend graph to determine the relationship between diameter and height in the measured individuals is given in Figure $6 a$ for healthy individuals and Figure $6 b$ for infected individuals. 
It is thought that the maintenance interferences which the Scots pines exposed to mistletoe undergo until they lose their vital functions may cause a serious cost burden to the FMs. It was calculated that the annual maintenance cost covering the parameters such as identification and marking of the future trees, determination of the individuals to be cut off from the field and removal of these individuals from the field, labour costs and transportation expenses have been estimated as $78.81 \$ /$ ha. It has been determined that the land value is $78.81 \$ / \mathrm{ha}$ and the annual land expenses are $12.26 \$ / \mathrm{ha}$ from the records of Gümüşhane Forest Management Directorate.

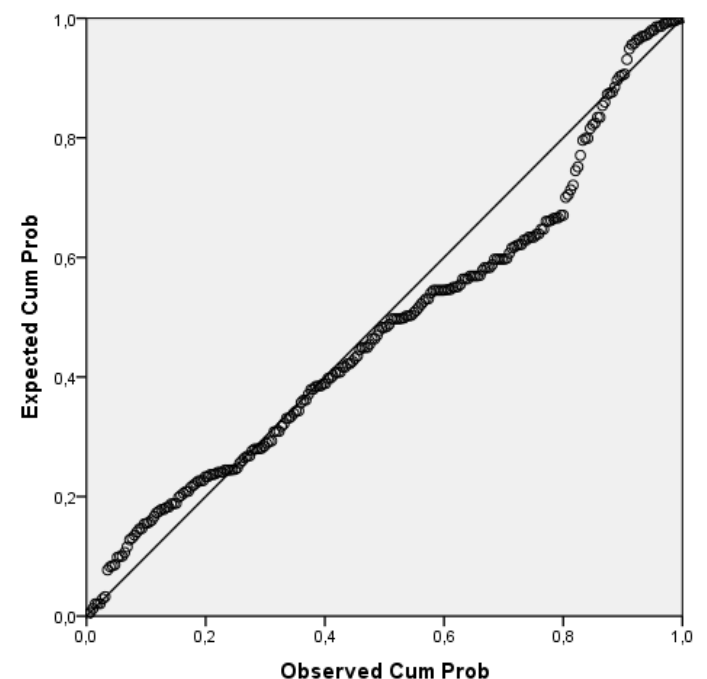

(a)

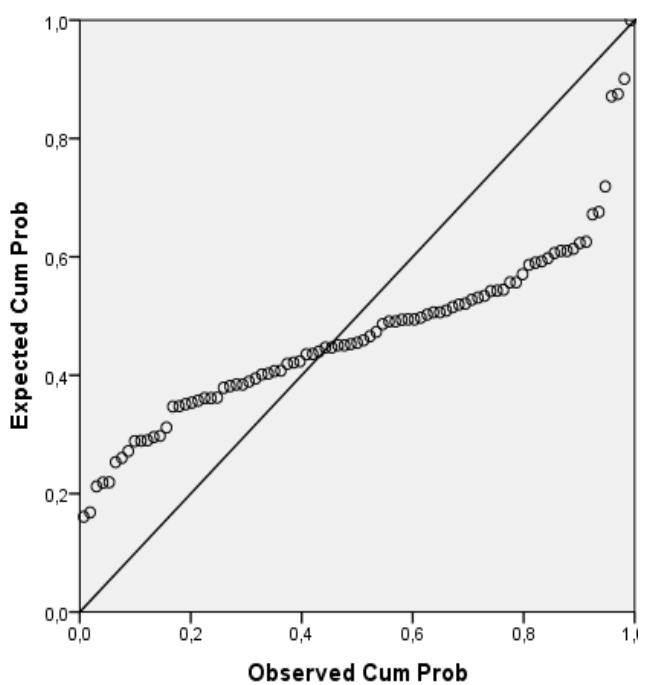

(b)

Figure 6. Statistical comparisons concerning mistletoe contamination

The products occurred in the maintenance of healthy individuals with $d_{130}$ chest diameters of more than $8 \mathrm{~cm}$ are offered for sale in forest depots or ramps at a cost value. The products formed during the maintenance processes of the individuals with mistletoe contamination are put upon to the market as firewood regardless of the product class. The absence of any enterprises producing paper, fibre and particle boards in the region can be said to increase the revenue loss of FMs in the products where mistletoe contamination is observed.

It is understood that the afforestation and natural regeneration areas will lose the economic value of the individuals in the areas to a great extent before reaching the targeted administration period due to the mistletoe damage. Therefore, the necessity of reforestation of these areas emerges. Gümüşhane Forest Management Directorate, the unit responsible for the study area of this research, reported that the cost of reforestation in these areas is $874.29 \$ / \mathrm{ha}$ and the cost of regeneration is $524.58 \$ / \mathrm{ha}$.

In the tree assets cost estimations we conducted (TACV), it was determined that 10 years ago 338.38 \$ product was obtained from the area and that the stands were at the end of the 1st year class, meaning 20 years old, by making use of the management plans. As a result of the analysis, the TACV was identified to be approximately $1224.86 \$$. Besides, it was found that mistletoe caused approximately $21 \%$ loss from each targeted $1 \mathrm{~m}^{3}$ forest product revenue in the study areas where the average contamination was found as $27 \%$ (Table 4). In the determination of this damage, the cost of firewood was taken into consideration for all targeted forest product varieties. 
Table 4. The damage detected in the target forest products

\begin{tabular}{|c|c|c|c|}
\hline Product type & Price $\left(\$ / \mathbf{m}^{3}\right)$ & Economic damage $\left(\$ / \mathbf{m}^{3}\right)$ & Economic damage rate $(\%)$ \\
\hline $\log$ & 27.32 & 5.85 & 21 \\
\hline Mine pole & 23.06 & 4.79 & 21 \\
\hline Pole & 20.22 & 3.64 & 18 \\
\hline Paper firewood & 18.80 & 4.08 & 22 \\
\hline Average & 22.35 & 4.59 & 21 \\
\hline
\end{tabular}

\section{Conclusions}

The results of this study have proved that mistletoe can be effective in both natural regeneration and afforestation areas. The average contamination rate was determined as $27 \%$. On the other hand, it is understood that mistletoe has an average revenue loss potential of $21 \%$ for the target forest products for the research areas. However, in the case that a decrease in revenue loss and forest products in the desired quality are wanted, additional costs must be endured.

According to the results of the study, mistletoe is more effective in afforestation areas when compared with natural regeneration areas in terms of distribution. Seed trees where mistletoe has occurred in the natural regeneration areas have an important effect on the increase of mistletoe spread in these areas.

At the same time, mistletoe occurrence negatively affects length and diameter growth in individuals. Therefore, it is seen that mistletoe causes quality and quantity loss in terms of forest products in natural regeneration and afforestation areas.

In future research, it will be useful to consider the effect of mistletoe on natural rejuvenation and afforestation sites on the basis of different tree species.

Acknowledgements. This study is a part of a master thesis entitled "The Increment-Growth Relationships and Economic Conditions of Scots Pine Natural Regeneration and Afforestation Areas: Gümüşhane Case" prepared by Murat Han ERTUĞRUL under the supervision of Assistant Professor Osman KOMUT in Gümüşhane University. This research was supported by Gümüshane University Scientific Research Projects Coordinator (Project No: 18.B0122.07.01).

\section{REFERENCES}

[1] Anonymous (1998): http://www.parasiticplants.siu.edu/Viscaceae/index.html.

[2] Bilgili, E., Eroğlu, M., Yavuz, H., Yılmaz, M. (2014): Determination of the spread of mistletoe (Viscum album L.) on Scotch pine (Pinus sylvestris L.) stands in Eastern Black Sea Region and modeling of its effect on diameter increase. - TUBITAK Project, Project No: 1120258, Trabzon.

[3] Çatal, Y., Carus, S. (2011): Effect of pine mistletoe on radial growth of Crimean pine (Pinus nigra) in Turkey. - J. Environ. Biol. 32: 263-270.

[4] Eroğlu, M. (1993): Mistletoe (Viscum album L.) in Scots Pine forests. - Journal of Forest Engineering 7: 6-10.

[5] Eroğlu, M., Başkaya, Ş. (1995): Causes and consequences of severe damage of mistletoe (Viscum album L.). - Journal of Forest Engineering 4(32): 25-31.

[6] Fidan, M. S., Yaşar, Ş. Ş., Yaşar, M., Atar, M., Alkan, E. (2016): Combustion characteristics of impregnated and surface treated chestnut Castanea sativa Mill wood left outdoors for one year. - BioResources 11(1): 2083-2095. 
[7] Frochot, H., Salle, G. (1980): Methods of dispersal and implantation of mistletoe. Revve-Forestiere-Francaise 32(6): 505-519.

[8] Gejdoš, M., Lieskovský, M., Giertliová, B., Němec, M., Danihelová, Z. (2019): Prices of raw-wood assortments in selected markets of central Europe and their development in the future. - BioRes. 14(2): 2995-3011.

[9] Glatzel, G. (1983): Mineral nutrition and water relations of hemiparasitic mistletoes a question of partitioning experiments with Loranthus europaeus on Quercus petraea and Quercus robur. - Oecologia 56(2-3): 193-201.

[10] Göl, Ç., Serdar, B., Öztürk, M., Kadir, A., Bilgili, E. (2018): Viscum album L. subsp. austriacum (Wiesb.) Vollman (Pine mistletoe) effect of Pinus sylvestris L. (Scots Pine) on wood elements. - Duzce University Journal of Science and Technology 6: 1354-1363.

[11] Janssen, T. (2001): Zur gemeinen Mistel (Viscum album L.). - Forst und Holz 56: 215219.

[12] Kanat, M., Alma, M. H., Sivrikaya, F. (2010): The effect of Viscum album L. on annual diameter increment of Pinus nigra Arn. - African Journal of Agricultural Research 5(2): 166-171.

[13] Luppold, W. G., Bumgardner, M. S. (2019): Changes in the quality of the Northern U.S. hardwood timber resource from 2008 to 2017. - BioRes. 14(3): 6304-6315.

[14] Malinen, J., Haring, M., Kilpeläinen, H., Verkasalo, E. (2015): Comparison of alternative roundwood pricing systems - a simulation approach. - Silva Fenn. 49(3): 1293.

[15] Merganič, J., Merganičová, K., Marušák, R., Tipmann, L., Šálek, L., Dragoun, L., Stolariková, R. (2016): Relation between forest stand diversity and anticipated log quality in managed Central European forests. - International Journal of Biodiversity Science, Ecosystem Services \& Management 12(1-2): 128-138.

[16] Mutanen, A., Toppinen, A. (2007): Price dynamics in the Russian-Finnish roundwood trade. - Scand. J. Forest Res. 22: 71-80.

[17] Öztürk, A. (2010): Artvin Forest Regional Directorate participating in auction sales determination of customers' demands and expectations. - Artvin Çoruh University Faculty of Forestry Journal 11(2): 61-73.

[18] Popp, M., Richter, A. (1998): Ecophysiology of Xylem-Tapping Mistletoes. - In: Behnke, H.-D. et al. (eds.) Progress in Botany: Genetics Cell Biology and Physiology Ecology and Vegetation Science. Springer, Berlin, pp. 659-674.

[19] Rast, E. D. (1974): Log and Tree Sawing Times for Hardwood Mills. - Research Paper NE-304. U.S. Department of Agriculture, Forest Service, Northeastern Forest Experiment Station, Upper Darby, PA.

[20] Sekendiz, O. A. (1984): Important insects in our forests can be seen bark beetles. Scolytidae (Apidae) Family Species, Protection and Control Methods, 16-24 April 1984, Antalya-İncekum Forest Insect and Diseases Seminar.

[21] Sönmez, T. (2014): The effect of mistletoe on the development of Scots Pine (Pinus sylvestris L.). - Artvin Coruh University Journal of Forestry Faculty 15(1): 64-72.

[22] Tennakoon, K. U., Pate, J. S. (1996): Effects of parasitism by a mistletoe on the structure and functioning of branches of its host. - Plant Cell and Environment 19(5): 517-528.

[23] Türker, M. F. (2013): Forestry Business Economics. Updated and Expanded 2nd Ed. Foundation for the Protection of Forestry and Nature Publication No. 5.

[24] Yaşar, Ş. Ş., Fidan, M. S., Yaşar, M., Atar, M., Alkan, E. (2016). Determining the effect of seasonal variation in spruce Picea orientalis L. wood treated with various impregnations on combustion resistance. - BioResources 11(4): 9467-9479.

[25] Yüksel, B., Akbulut, S., Keten, A. (2005): Damage, biology and control of Pine Mistletoe (Viscum album ssp. austriacum (Wiesb.) Vollman). - Süleyman Demirel University Journal of the Faculty of Forestry 2: 111-124.

[26] Zuber, D. (2004): Biological Flora of Central Europe: Viscum album L. - Geobotanisches Institut ETH, Zürich. 